\title{
Anadolu University Open Education Faculty Students' Opinions on the Use of Artificial Intelligence Based Systems and Applications
}

DOI: 10.26466/opus.937331

\author{
Nil Göksel ${ }^{*}$ \\ * Dr., Anadolu Üniversitesi, Eskişehir/Türkiye \\ E-Mail: ngoksel@anadolu.edu.tr \\ ORCID: $0000-0002-3447-2722$
}

\begin{abstract}
This study aims to examine to what extent are the students aware of the AI based systems used in language learning. The design of the study was determined as a quantitative research method. For this purpose, a web-based questionnaire was applied to 204 students with A1 and A2 English levels enrolled in the Open Education Faculty, and thus data were collected about the students' views on Artificial Intelligence-based systems that they use to improve their English speaking and writing skills. The data obtained from the students were analyzed using descriptive statistical procedures such as frequency and percentage analysis. The findings of the study revealed that many of the distance education students do not have an idea whether AI-based applications have an effect on improving their English 'speaking' skills. It also showed that most students who participated in this study had no idea whether these practices had an effect on improving their English 'writing' skills. In this context, the study proves that students are limitedly aware of Artificial Intelligence-based systems used while learning foreign languages, and therefore, more studies on the subject should be conducted and these systems should be introduced to students.
\end{abstract}

Keywords: Artificial Intelligence Based Systems, Distance Education, Foreign Language Learning, Open Education Faculty Students. 


\section{Anadolu Üniversitesi Açıöğretim Fakültesi Öğrencilerinin Yapay Zekâ Tabanlı Sistemlerin Kullanımı ve Uygulamalarına İlişkin Görüşleri}

\section{Öz}

Bu çalışma, Açık̈̆ğretim Fakültesi öğrencilerinin yabacı dil öğrenirken kullandıkları Yapay Zekâ tabanlı sistemler hakkında ne kadar haberdar oldukların incelemeyi amaçlamaktadır. Çalışmanın deseni nicel araştırma yöntemi olarak belirlenmiştir. Bu amaçla, Açıöŏgretim Fakültesine kayıtlı A1 ve A2 İngilizce seviyelerine sahip 204 öğrenciye web tabanlı bir anket uygulanmış ve böylece öğrencilerin İngilizce konuşma ve yazma becerilerini geliştirmek için kullanıldıklar Yapay Zekâ tabanlı sistemlere ilişkin görüşleri hakkında veriler toplanmıştır. Öğrencilerden elde edilen veriler, frekans ve yüzde analizi gibi betimsel istatistik prosedürleri kullanılarak analiz edilmiştir. Araştırmanın bulguları, uzaktan eğitim öğrencilerinin birçoğunun Yapay Zekâ temelli uygulamaları İngilizce 'konuşma' becerilerini geliştirmede etkisi olup olmadı̆̆g konusunda fikir sahibi olmadıklarını ortaya koymuştur. Ayrıca, bu çalışmaya katılan çoğu öğrencinin, bu uygulamaları İngilizce 'yazma' becerilerini geliştirmede bir etkisi olup olmadığı konusunda bir fikri olmadığııı göstermiştir. Bu bağlamda çalışma, öğrencilerin yabancı dil öğrenirken kullanılan Yapay Zekâ temelli sistemlerden sınırlı ölçüde haberdar olduklarını ve bu nedenle konu ile ilgili daha fazla çalışma yapılması ve bu sistemlerin öğrencilere tanıtılması gerektiğini kanıtlamaktadır.

Anahtar Kelimeler: Yapay Zekâ Tabanlı Sistemler, Uzaktan Eğitim, Yabancı Dil Öğrenimi, Açıköğretim Fakültesi Öğrencileri. 


\section{Introduction}

With the recently developed software enhanced by Artificial Intelligence (AI), the domination over knowledge has been evolved and this causes AI to become prominent in higher education. AI based technologies, including machine learning, deep learning, and Natural Language Processing (NLP) enable machines to accomplish specific human-like tasks, and process new inputs and large amounts of data. Since AI's presentation to humanity in 1950s (Webber and Nilsson, 2014), learners have become individuals who can organize their personal agendas and become autonomous learners. The traits of AI associated with a human mind is to take actions that have the best chance of achieving a specific educational goal. By becoming involved in AI, both learners and instructors may have an opportunity to comprehend how the simulation of human intelligence works in terms of learning and problem-solving within the scope of distance education.

In distance education context, AI technologies have been used for a while. The research into AI based technologies in distance education can be categorized into two, namely intelligent learning systems and learners. For intelligent learning systems, AI based technologies have been used as enhancers in Open and Distance Learning (ODL) systems. In terms of learners, AI based technologies have become research focus for success rate, performance, academic achievements, and learning accomplishments (Isik and Aslan, 2015). Furthermore, user-intelligent adaptive learning models can be created, thanks to AI based technology and in distance education context, learning characteristics are diverse, which poses a problem that could be solved with such models (Sivakumar, Venkataraman and Gombiro, 2015). Considering learners' different interests motivation levels, proficiency levels, personal responsibilities, preferences and learning paces in distance education, AI based tutoring systems have potentials to individualize learning (Dolenc and Aberšek, 2015). AI technologies also have advantages of breaking the space time linking between instructors and learners in ODL contexts (Nenkov, Dimitrov, Dyachenko and Koeva, 2016).

Around the world many institutions make use of AI based technologies in their distance education programs. There are various studies conducted 
on the use of AI based applications specifically in foreign language education, but they are limited. Within the context of language teaching/learning, the learner text and the dialogue systems afforded by NLP may lead to meaningful communications (Lu, 2018). Dragon transcription software, for instance, which was integrated into Windows in the 1990s and transcribes text without speaking, has shown benefits for foreign language learning, especially with regard to pronunciation. (Campbell, 2017). Moreover, machine learning and NLP have had a major impact on teaching English (Al Emran and Shaalan, 2014) and with the automated feedback in which effective and rapid responses are provided in seconds, AI based applications have become crucially important in foreign language learning (Boud and Molloy, 2013). However, despite many attempts by AI towards education, there is still insufficient evidence of the effectiveness of AI-based projects in improving language learning on a large scale (Kannan and Munday, 2018).

The potentials of AI based technologies in ODL context have been searched and defined, yet these technologies work on one condition, that is, if they are known. Therefore, more studies are needed to create awareness towards potentials of $\mathrm{AI}$ in distance foreign language learning. Due to limited empirical research involving views of learners in open and distance foreign language learning context, this study sets out to investigate opinions of Open Education Faculty (OEF) students of Anadolu University in Turkey regarding their use of AI based systems in the process of developing English speaking and writing skills. In other words, it will display how well the learners are aware of AI based systems for English learning. With all these ideas in mind, answers to the following questions are sought:

RQ1. To what extent are the students aware of the AI based systems used in language learning?

RQ2. Which AI based systems would students use to improve their English-speaking skills?

RQ3. Which AI based systems would students use to improve their English writing skills? 


\section{Related Literature}

\section{Artificial Intelligence in Education}

There have been path-breaking developments recently in AI and the studies conducted in this field are still up to its limits. Therefore, AI, as a wideranging branch of computer science is progressing rapidly. With its working structure, AI has surprised humanity lately and started playing a notable role in education and that needs close attention. With a system that can learn on its own (Adams, 2017), AI has become capable of pretending humans with cognitive features such as perception, learning, connecting plural concepts, deep thinking, problem solving, communicating and decision making. In addition, the concept has been started to be used for various purposes including automated grading, feedback, interaction, practice, adaptive learning programs, tutoring, trial-and-error learning practices, recommendation systems and user modelling (Looi, McCalla and Bredeweg, 2005; McCalla, 2000; Roll and Wylie, 2016; Timms, 2016). Thereby, necessary information can be selected arbitrarily, evaluated accurately, and responded accordingly to the specific commands of the learners.

Artificial intelligence has entered the field of education in response to the increasing demand for individual learning as well as the competitive business sector. With the need for pedagogical advice in learning (Alhabbash, Mahdi and Naser, 2016) and the attempts to incorporate personalised, adaptable, 'human-like' features to online milieus (Fadzil and Munira, 2008), AI based technologies seem to have a potential to make benefit to promote individual and autonomous learning. Thus, web-based educational systems are forming a new development paradigm in the field of AI in education and this paradigm would let new educational attempts to put into practice in real life (Brusilovsky and Peylo, 2003).

Although the issue of lecturing with AI based intelligent systems and smart robots are still under discussion, they are hoped to be justified by the pedagogical approaches of distance education. So far, intelligent boots like Snatchbot, Botsify, Ozobot, MATHiaU, Chatfuel, Flowxo, Motion.ai Morph.ai, ChattyPeople (Paul, Haque-Latif, Amin-Adnan and Rahman, 2018), Morph.ai, Flowxo, Motion.ai, ChattyPeople, Chatfuel, Meokay, 
Smooch, Botkit (Jyothirmayi, Soniya, Grace and Murthy, 2019) have been started to be used effectively. Snatchbot (n.d.) as an online medium; for instance, helps instructors to engage more students into their personalized bot according designed for their educational needs. Botsify (n.d.) as a Facebook chatbot platform leads to create and integrate other chatbots into automated system and provides enterprise-level solutions for English learning. Ozobot (n.d.) may help instructors to teach coding and MATHiaU (n.d.) provides an efficient learning experience to Math learners of higher education.

\section{Artificial Intelligence in Foreign Language Learning}

When machine-human interaction is predicted to be long-term, it seems inevitable to use AI based systems that can be used effectively to learn and teach English as a foreign language. Especially in the field of distance education, which can integrate technological innovations into online classrooms, different feedback methods can be used (Borup, West and Thomas, 2015) and through these new methods, learners can receive synchronous or asynchronous feedback that may result with positive learning outcomes (Goldsmith, 2014).

The AI-based software with touch screen virtual keyboards and voice control structures can assist students to improve their speech dialogues with machines. On that note, the authentic communication between humans and machines seem to open a new path to investigate how Intelligent Personal Assistants (IPAs) like Siri, Cortana, Google Assistant, Ruuh and similar technologies can foster second and foreign language development both in and outside of the classroom (Dizon, 2017). Another sample of these technologies is Engkoo, which transforms any computer into a language learning assistant and thus adds innovation to speech processing technology (Wang, Qian, Scott, Chen and Soong, 2012).

AI-based software used in distance foreign language learning contexts generally apply NLP, which responds to human input with the highest level in terms of grammatical parsing, reordering, discourse-parsing, semantic relationship classification, question-answer, modelling the relationship between character sequences (Goldberg, 2016). Having a similar NLP pattern, IPAs namely Google Now, Apple Siri, Microsoft Cortana, 
and Amazon Alexa are some of the examples of AI-based software that could be used for enhancing speaking skills. In particular, Alexa was found to be useful pedagogically and it allowed students to receive indirect feedback and to increase opportunities to orally interact in the target language (Dizon, 2017). Another study examined the existing AI based technologies to be used for answering common questions asked in the language classrooms by children. According to the results obtained, IPAs were found highly engaging, and make students feel to speak more English when using IPAs in group work (Underwood, 2017). In this connection, it may be assumed that students can improve their foreign language skills with these AI based software that can be reached 24/7.

Of that software, Intelligent Language Tutoring Systems (ILTSs) use NLP techniques to allow free entry of words and sentences by the language learners. With these systems, receptive skills, namely reading and listening, and productive skills like speaking and writing can be supported according to the learner needs. With the development of automated scoring and feedback systems, learners can be involved in tasks with which they can improve reading, listening, speaking, writing, vocabulary, and grammar skills. In foreign language learning, it is more difficult to acquire speaking and writing skills compared to others. In this connection, AI based tools to be used in the acquisition of these effort-seeking skills are the tools that may develop students to learn by themselves. Therefore, ILTSs are of paramount importance in language learning especially with their computer-based tutors that make use of AI techniques (Heift, 1998).

ILTSs, with their specially designed structures for language learning, may involve specific feedback to learners based on information that they enter into the computer, and thus positive learning experiences are obtained for students in language learning milieus (Tafazoli, María and Abril, 2019; Heift and Nicholson, 2001). Programs like Criterion, WriteToLearn, MY Access!, WriteLab, Summary Street ${ }^{\circledR}$ help learners to be responded virtually concerning revisions and editing of their submitted works. Referring to the research done on ILTSs, some of the wellknown samples used for foreign language learning include Grammarly for English (grammar), W-Pal for English (writing), Sentence Fairy for 
German (writing, grammar), E-Tutor for German (listening, reading, writing, vocabulary, grammar); TAGARELA for Portuguese (listening, reading, writing, vocabulary, grammar) and Robo-Sensei for Japanese (grammar) (Heift, and Vyatkina, 2017). The above-mentioned software, generating feedback by using NLP, provide relevant possible correct answers and detects error in seconds.

Through accurate and timely formative feedback provided by AIbased applications, students can reach the information they look into in a short time, and they can be clear and more confident in their next learning attempts (Puspitasari, 2010). In various studies, it was claimed that automatic feedback had a positive effect on writing skills (Wang et al., 2012), and increased learners' awareness of autonomy and motivation (Link, Dursun, Karakayam and Hegelheimer, 2014; Wang et al., 2012; Williams, 2005; Taskiran and Yazici, 2021).

Despite the studies that refer to the positive aspects of the intelligent systems mentioned above, there are still inadequacies of the AI based applications used in distance education (Schulze, Heift, Thomas, Reinders, and Warschauer, 2013). When machine-human interaction is predicted to be used effectively in distance education, AI based systems seem promising and long lasting. In this regard, it is crucial to peruse to what extent are the students aware of the AI based systems to foster their language learning. In this context, more studies should be conducted on foreign language learning of distance learners using AI-based applications (Cotos, 2011).

\section{Methodology}

\section{Research Design}

This is a quantitative survey study which aims to determine the opinions of OEF students about AI based applications used while learning English. In line with this aim, descriptive analysis procedures such as frequency and percentage of the scores are used to show the tendencies of the participants of the questionnaire. "Descriptive statistics is used to summarize the overall trends or tendencies in data, provide an understanding of how 
varied the scores might be, and provide insight into where one score stands in comparison with others" (Creswell, 2012, p.183).

The survey method involves collecting data to test hypotheses or answer questions about people's views on a specific topic or a problem and to gather information about a group's beliefs, attitudes, behaviors and demographic structures (Mills and Gay, 2019). In this connection, this research method involved collecting data through a web-based questionnaire prepared by the researcher to determine the opinions of OEF students on AI based applications used while learning English. In order to comply with ethical rules, Ethical Board Permission (dated 2021/numbered 51578) of Anadolu University was received.

\section{Participants and settings}

The participants of the study were Anadolu University OEF students with A-1 and A-2 English levels. Of 204 participants, 73 were male and 131 were female. The ages of participants were between 18 and 51. Participants were enrolled in 30 associate and undergraduate programs within Anadolu University Open Education, Economics and Business Administration Faculties. While 112 of the students were studying associate degree programs, 92 of them were studying undergraduate programs. 21-10 students from Social Services, Business Administration, Sociology, Political Science and Public Administration, Turkish Language and Literature and Public Relations and Advertising programs, 8-6 students from Healthcare Institutions Management, Medical Documentation and Secretariat, Public Relations and Publicity, Office Management and Executive Assistance, Justice, Foreign Trade, Laboratory and Veterinary Health programs; 5 or less students out of 18 programs participated in the research. This study was conducted in a closed Facebook group called 'Distance Learners'.

The setting of the study contains an online educational platform, which has been carried out virtually since 2014, and it was set up specifically for OEF learners. To invite the participants to the research, the researchers posted a virtual message regarding the subject matter and of these members, the volunteered participants accepted to take part in this study. 


\section{Data Collection}

In order to determine the opinions of OEF students about AI based applications used while learning English, a web-based questionnaire was prepared. The questionnaire consisted of two parts. In the first part, there were 3 questions about demographic variables such as gender, age, and the part read, while in the second part, students' English levels, the methods they used to improve their English speaking and writing skills, and their weekly spend, AI based practices that they used to improve their English speaking and writing skills. There were 13 questions regarding weekly usage times and the effect of AI based applications on improving English speaking and writing skills. Opinions of 8 experts from distance education and 4 instructors in the field of foreign language education were received. The opinions of the experts and instructors were examined and the questionnaire items were finalized. The prepared questionnaire was transformed into Google Form and made web-based.

The short link of the prepared questionnaire form was shared with a text containing the purpose and importance of the research in the Distance Learning group on Facebook. A total of 220 responses came to the questionnaire at the end of the period. Incorrect and duplicate responses were cleared and the data analysis process was initiated for the answers of 204 participants.

\section{Data Analysis}

This is a quantitative survey study. In this study, the collected data were analyzed descriptively in order to determine the opinions of OEF students about AI based applications used while learning English. To begin with web-based survey data were entered into IBM SPSS Statistics 24 program and made ready for data analysis. Then, the data collected for each item were analyzed and frequency and percentage calculations were made. 


\section{Findings}

The data were collected within the scope of this descriptive research that aimed to determine the views of OEF students on AI based applications used while learning English. According to the analysis obtained, the findings can be listed as:

- Students' perceived general English levels;

- English speaking and writing levels;

- Methods used for English speaking and writing skills and AI based applications;

- The time spent on methods and applications;

- The effect of AI based applications.

Table 1. Perceived English Proficiency Levels of Open Education Students

\begin{tabular}{lllllllll}
\hline & \multicolumn{2}{l}{ Basic Level } & \multicolumn{2}{l}{ Intermediate Level } & \multicolumn{2}{l}{ Advanced Level } & Total & \\
\cline { 2 - 9 } & $\mathbf{f}$ & $\mathbf{\%}$ & $\mathbf{f}$ & $\mathbf{\%}$ & $\mathbf{f}$ & $\mathbf{\%}$ & $\mathbf{f}$ & $\mathbf{\%}$ \\
\hline General English & 131 & 64,2 & 69 & 33,8 & 4 & 2,0 & 204 & 100 \\
Speaking & 154 & 75,5 & 50 & 24,5 & 0 & 0 & 204 & 100 \\
Writing & 130 & 63,7 & 65 & 31,9 & 9 & 4,4 & 204 & 100 \\
\hline
\end{tabular}

When Table 1 was examined, it was seen that more than $60 \%$ of OEF students expressed that their General English proficiency, speaking and writing levels were at the basic level. While only 4 of the students stated that their General English proficiency was advanced and 9 of them stated that their writing skills were advanced, none of the students stated that their speaking skills were advanced. When these findings were evaluated, it could be indicated that most of the students saw themselves at the basic level and very few students think that they were at the advanced level in all three competency areas. 
Table 2. Development Methods of Open Education Students' Speaking and Writing Skills

\begin{tabular}{|c|c|c|c|c|c|}
\hline \multicolumn{3}{|l|}{ Development Methods of Speaking Skills } & \multicolumn{3}{|l|}{ Development Methods of Writing Skills } \\
\hline & f & $\%$ & & $\mathrm{f}$ & $\%$ \\
\hline Doing nothing & 47 & 23,0 & Doing nothing & 74 & 36,3 \\
\hline $\begin{array}{l}\text { Using chatbots (Ruuh, Cortana, Siri, } \\
\text { Google Assistant) }\end{array}$ & 45 & 22,1 & $\begin{array}{l}\text { Using applications for writing (Crite- } \\
\text { rion, Write and Improve, WriteLab) }\end{array}$ & 31 & 15,2 \\
\hline $\begin{array}{l}\text { Talking to strangers, having a chat on } \\
\text { the internet }\end{array}$ & 17 & 8,3 & Writing essays & 4 & 2,0 \\
\hline Recording and listening to own speech & 3 & 1,5 & $\begin{array}{l}\text { Writing paragraphs with new words } \\
\text { learned }\end{array}$ & 33 & 16,2 \\
\hline Other & 92 & 45,1 & Other & 62 & 30,4 \\
\hline Total & 204 & 100 & Total & 204 & 100 \\
\hline
\end{tabular}

When Table 2 was examined, it was observed that $23 \%$ of the OEF students do not make any effort to improve their speaking skills and $36.3 \%$ of them to improve their writing skills. While $22.1 \%$ of the students stated that they used chatbots such as Siri, Cortana, Google Assistant and Ruuh to improve their speaking skills, $15.2 \%$ stated that they used applications such as Criterion, Write and Improve and WriteLab. 8.3\% of the students talk to strangers or having a chat on the internet; $1.5 \%$ by recording and listening to their speech; $45.1 \%$ stated that they tried to improve their English-speaking skills by using other different ways. Considering what students do to improve their English writing skills, it was seen that $2 \%$ stated that they wrote essays, $16.2 \%$ wrote paragraphs with the new words they learned, and $30.4 \%$ stated that they used other different ways.

Table 3. Weekly Time Spending by Open Education Students to Improve Their Speaking and Writing Skills

\begin{tabular}{|c|c|c|c|c|c|c|}
\hline \multicolumn{3}{|c|}{ Time Spent on Speaking Skills } & \multirow[t]{2}{*}{ Time } & \multirow[t]{2}{*}{ on } & Writing & \multirow[t]{2}{*}{ Skills } \\
\hline & $\mathbf{f}$ & $\%$ & & & $\mathbf{f}$ & \\
\hline Never & 51 & 25,0 & Never & & 83 & 40,7 \\
\hline $0-1$ hour & 93 & 45,6 & $0-1$ hour & & 86 & 42,1 \\
\hline 2-4 hours & 50 & 24,5 & 2-4 hours & & 30 & 14,7 \\
\hline 5 hours and over & 10 & 4,9 & 5 hours and over & & 5 & 2,5 \\
\hline Total & 204 & 100 & Total & & 204 & 100 \\
\hline
\end{tabular}

When Table 3 was examined, it was observed that $25 \%$ of OEF students did not spend any time to improve their speaking skills and $40.7 \%$ of them 
to improve their writing skills. Looking at the time spent per week to improve their English-speaking skills, it was seen that $45.6 \%$ of the students said that they spent $0-1$ hours, $24.5 \% 2-4$ hours, and $4.9 \%$ said 5 hours or more. Looking at the time spent per week to improve their English writing skills, it was seen that $42.1 \%$ of the students said that they spent $0-1$ hours, $14.7 \% 2-4$ hours, $2.5 \%$ said 5 hours or more.

Table 4. Artificial Intelligence Based Applications Used by Open Education Students to Improve Speaking and Writing Skills

\begin{tabular}{llllll}
\hline \multicolumn{2}{l}{ Applications Used for Speaking Skills } & \multicolumn{5}{l}{ Applications Used for Writing Skills } \\
\hline I don't use & $\mathbf{6}$ & $\mathbf{\%}$ & & $\mathbf{f}$ & $\mathbf{\%}$ \\
Bixby & 126 & 61,7 & I don't use & 160 & 78,4 \\
Duolingo & 1 & 0,5 & Duolingo & 6 & 2,9 \\
Elsa & 8 & 3,9 & Google Translate & 3 & 1,5 \\
Google Assistant & 1 & 0,5 & Grammarly & 18 & 8,8 \\
Siri & 53 & 26,0 & Summary Street & 2 & 1,0 \\
Total & 15 & 7,4 & Write and Improve & 15 & 7,4 \\
\hline
\end{tabular}

When Table 4 is examined, it is seen that more than half of the OEF students do not use any AI based application to improve their English speaking $(61.7 \%)$ and writing $(78.4 \%)$ skills. Focusing on the AI based applications that students use to improve their English-speaking skills, it is seen that 26\% use Google Assistant, 7.4\% Siri, 3.9\% Duolingo, 0.5\% Bixby and $0.5 \%$ Elsa. It is seen that $26 \%$ use Google Assistant, $7.4 \%$ Siri, $3.9 \%$ Duolingo, 0.5\% Bixby and 0.5\% Elsa.

In addition, 3 students using Siri and 1 student using Bixby stated that they also used the Google Assistant application. Focusing on the AI based applications used by students, it is observed that $8.8 \%$ of them use Grammarly, $7.4 \%$ Write and Improve, 2.9\% Duolingo, 1.5\% Google Translate, $1 \%$ Summary Street. Moreover, 1 student using Grammarly stated that they also used Write and Improve application.

Table 5. Weekly Usage Period of Artificial Intelligence Based Applications of Open Education Students

\begin{tabular}{|c|c|c|c|c|c|}
\hline \multicolumn{3}{|c|}{ Duration of Using AI Applications for Speaking Skills } & \multicolumn{3}{|c|}{ Duration of Using AI Applications for Writing Skills } \\
\hline & $f$ & $\%$ & & $f$ & $\%$ \\
\hline Never & 116 & 56,9 & Never & 137 & 67,2 \\
\hline $0-1$ hour & 60 & 29,4 & 0-1 hour & 47 & 23,0 \\
\hline $2-4$ hours & 24 & 11,7 & 2-4 hours & 16 & 7,8 \\
\hline 5 hours and over & 4 & 2,0 & 5 hours and over & 4 & 2,0 \\
\hline Total & 204 & 100 & Total & 204 & 100 \\
\hline
\end{tabular}


When Table 5 is examined, it is seen that $56.9 \%$ of the OEF students stated that they did not spend time using any AI based application to improve their speaking skills and $67.2 \%$ of them to improve their writing skills. Considering the weekly AI based application usage time to improve their English-speaking skills, $29.4 \%$ of the students stated that they used AI based applications for $0-1$ hour, $11.7 \%$ for $2-4$ hours, $2 \%$ for 5 hours or more. When the authors focus on the weekly AI based application usage times to improve English writing skills, $23 \%$ of the students stated that they used AI based applications for $0-1$ hour, $7.8 \%$ for $2-4$ hours, $2 \%$ for 5 hours and more.

Table 6. Opinions of Open Education Students on the Effect of Artificial Intelligence Based Applications on Improving Speaking and Writing Skills

\begin{tabular}{llllll}
$\begin{array}{l}\text { Opinions on the Effect of Practices on Improving } \\
\text { Speaking Skills }\end{array}$ & \multicolumn{3}{l}{$\begin{array}{l}\text { Opinions on the Effect of Practices on Improving } \\
\text { Writing Skills }\end{array}$} \\
\hline & f & $\%$ & & f & $\%$ \\
\hline No idea & 117 & 57,4 & No idea & 129 & 63,2 \\
Not effective at all & 5 & 2,4 & Not effective at all & 4 & 2,0 \\
Not effective & 9 & 4,4 & Not effective & 2 & 1,0 \\
Effective & 66 & 32,4 & Effective & 61 & 29,9 \\
Very effective & 7 & 3,4 & Very effective & 8 & 3,9 \\
Total & 204 & 100 & Total & 204 & 100 \\
\hline
\end{tabular}

When Table 6 is examined, it is seen that $57.4 \%$ of the distance education students do not have an idea about whether AI based applications have an effect on improving their English-speaking skills. $63.2 \%$ of the students did not have an idea whether these practices had an effect on improving their English writing skills.

When the opinions about the effect of AI based applications on improving English speaking skills were examined, it is seen that $2.4 \%$ of the students stated that they were not effective at all, $4.4 \%$ of them were not effective, $32.4 \%$ of them were effective, and $3.4 \%$ of them stated that they were very effective. When the opinions about the effect of AI based applications on improving English writing skills are examined, it is seen that $2 \%$ of the students stated that they were not effective at all, $1 \%$ were not effective, $29.9 \%$ were effective, and $3.9 \%$ were very effective. 


\section{Discussion and Concluding Remarks}

This study got the opinions of OEF students of Anadolu University in Turkey regarding their use of AI based systems in the process of developing English speaking and writing skills. In this connection, the study displayed how much the learners were aware of AI based systems for English learning. The responds collected on voluntary basis proved that students were aware of AI based systems used in language learning to a limited extent, which create a need for the necessity to introduce the systems to the students.

In the study, the first research question aimed to detect "to what extent are the students aware of the AI based systems used in language learning?". With the development of artificial intelligence and voice interaction-based curricula in the field of education (Pokulevska, 2018), more studies have been carried out especially in the last 30 or more months (Nordrum, 2017). Accordingly, the recent studies signify the positive effects in language learning activity such as English as a foreign language (EFL) (Hamuddin and Dahler, 2018). Today, the tendency to learn a foreign language includes the desire to be fluent in the target language to be learned (Wiranti, 2013), and in this context, the use of AI in foreign language learning/teaching has become a practical choice (Abad, 2013). In a study conducted by Berdasco, López, Diaz, Quesada and Guerrero (2019), the results of the evaluation with 92 participants showed that $99 \%$ of the users were aware of the existence of smart personal assistants such as Google Assistant, Alexa, Cortana, and Siri, but only $86 \%$ had used at least one of them. These rates are proof that the use of these tools is rare. In support of this statement, the findings obtained in this study also determined that most of the students were rarely aware of the existing AI based systems used in distance foreign language learning.

When considered within the context of ODL, it is realized that distance foreign language teaching becomes more difficult especially for instructors (Kessler and Plakans, 2008). One of the options in overcoming the challenges in open and distance learning is 'interaction' (Simonson, Smaldino, Albright and Zvacek, 2006), which may include regular, continuous and effective feedback with AI-based applications in online milieus. In this connection, some researchers viewed AI based IPAs as valuable tools as 
they could maintain online interaction and promote L2 acquisition specifically for speaking and listening skills and related vocabulary (Moussalli and Cardoso, 2020). In this connection, these tools that improve individual learning are worth studying in detail with their educational potential; however, students' attention should be directed primarily to these tools. Many apps namely Duolingo, Kahoot, Quizlet pervaded the language learning and so let learners become more autonomous users who learn beyond their traditional classroom borders (Kannan and Munday, 2018). In this connection, more applications could be presented to learners in order to inform them.

The second research question aimed to detect "which AI based systems would students use to improve their English-speaking skills?" In some studies, it is depicted that functional and topical use of a digital assistant tends to vary by individual choice (Kumar et al., 2016). For nonnative English-speaking students, AI based IPAs like Apple Siri, Google Assistant/Now, Amazon Alexa and Amazon Echo can be used for different purposes such as setting timers or alarms, weather, entertainment and music, facts and information, and dictating texts/calling (Lopatovska, et.al, 2019). In terms of its pedagogical use of technologies, Amazon's Echo can contribute to traditional face-to-face L2 teaching as they have the potential to enhance in both quantity and quality the input that learners receive (Moussalli and Cardoso, 2020). Whether this contribution also applies to distance learners who are non-traditional and who are completely separated from their instructors should be examined in more detail as well.

AI based systems may mostly be used for basic personal task management functions so they meet the user needs in general (Brill, Munoz and Miller, 2019); however, this issue needs to be addressed in a more educational level within the scope of language learning. In some studies, L2 learners have no problems understanding some AI based IPAs as they adapt well to learners' accented speech. In this regard, IPAs expose learners to oral input that is abundant and of good quality, and provides them with both input/listening and output/speaking opportunities through human-machine interactions (Moussalli and Cardoso, 2020). According to the results obtained in this study, Google Assistant, Siri, Duolingo, Bixby and Elsa were the only apps preferred to be used by the OEF learners for 
language learning purposes and as it is seen on Table 4, more than fifty percent of the OEF students do not use any AI based applications to improve their English-speaking skills. This huge percentage show that students may not be aware of the existing applications. While discussing the systems that improve speaking skills, the difficulties they cause for the users should be carefully examined as well.

The third research question aimed to detect "which AI based systems would students use to improve their English writing skills?". One of the most important criteria in developing writing skills is getting feedback from instructors. As indicated in various studies in literature, timely and effective feedback is crucial (Moore and Kearsley, 2012) and writing as a certain skill in foreign language learning needs continuous feedback from the instructor (Andersen, Yannakoudakis, Barker and Parish, 2013) in order to increase the success of the learners (Daneshvar and Rahimi, 2014). Thanks to the intelligent software online corrections, which students can see their mistakes more clearly and get instant feedback that foster EFL their writing (Wang and Wang, 2012). Automated feedback systems might be promising for the improvement of writing as a productive skill as they give regular formative feedback to the learners (Andersen, Yannakoudakis, Barker and Parish, 2013). As seen on Table 4, more than fifty percent of the OEF students do not use any AI based applications to improve their English writing skills. Based upon these results, it can be calculated that students were not aware of the existing systems used to enhance their writing skills.

Artificial Intelligence as a unified system takes, defines, evaluates and responds learner needs with an impressive accuracy that can be used effectively in distance foreign language teaching and learning. In other words, it serves in a smooth computing technology that often uses AI. In this connection, this study may provide implications in that the results revealed the crucial necessity for the awareness of the existing AI systems to be used for throughout the process of developing English speaking and writing skills. In addition, the study has highlighted the necessity of introducing these systems to the students by the instructors at the very beginning of the learning action.

It can also be concluded that most of the OEF students in this study whose English was at a basic level usually took no action to improve their 
speaking and writing skills. This was not because they were actually unwilling, but because they were unaware of the programs that exist. When adequately informed and guided correctly, students could achieve their language development with AI-based tools.

\section{Limitations and Suggestions for Future Research}

The results of this study were based on quantitative analysis using descriptive statistical procedures such as frequency and percentage analysis. However, the findings of the study are only limited with productive skills namely speaking and writing in English. Therefore, in future studies, receptive skills like reading and listening can be examined within the scope of distance foreign language learning with AI based technologies.

According to the data obtained in this study, the majority of the students did not have an idea whether AI-based tools were effective in improving their English-speaking skills. Therefore, the existing situation actually displays the general picture of OEF students' attitude towards using these applications. In this connection, future research may include deeper insights that can be conducted with qualitative research designs consisting of interviews and observations presented in narrative form.

The study also proves that students seemed to be aware of AI based systems used in language learning to a limited extent and therefore they cannot benefit from the existing tools. Therefore, more studies on the subject should be done and these systems should be introduced to students who struggle to learn English as a distance. Also, detailed data can be collected from other OEF students not only in Turkey but also in other world institutions.

Distance education is a system that puts the responsibility of learning completely on the student. However, in order to ensure that students are not isolated in their learning process, open and distance education institutions can prepare introductory content regarding the use of AI-based applications for distance foreign language learning and offer these tools to students in their learning management systems. In addition, these tools can be included in the curriculum and certain assignments and can be presented in some live lessons by the instructors. Finally, at certain intervals during the semester, whether these tools work or not can be examined by 
taking the students' opinions. Thus, by conducting more studies on distance foreign language learning, more information can be obtained on AIbased applications that students can benefit from, so theoretical knowledge can be put into practice.

\section{References}

Abad, J. V. (2013). Pedagogical factors that influence EFL teaching: Some considerations for teachers' professional development. Profile Issues in Teachers Professional Development, 15(1), 97-108.

Adams, R.L. (2017). 10 Powerful Examples of Artificial Intelligence in Use Today. Forbes.

Al Emran, M. and Shaalan, K. (2014). A survey of intelligent language tutoring systems. In 2014 International Conference on Advances in Computing, Communications and Informatics (ICACCI) (p.393-399). IEEE.

Alhabbash, M. I., Mahdi, A. O., and Abu Naser, S. S. (2016). An Intelligent Tutoring System for Teaching Grammar English Tenses. European Academic Research, 6(9), 7743-7757.

Andersen, Q. E., Yannakoudakis, H., Barker, F. and Parish, T. (2013). Developing and testing a self-assessment and tutoring system. In Proceedings of the eighth workshop on innovative use of NLP for building educational applications (p.32-41).

Berdasco, A., López, G., Diaz, I., Quesada, L. and Guerrero, L. A. (2019). User experience comparison of intelligent personal assistants: Alexa, Google Assistant, Siri and Cortana. In Multidisciplinary Digital Publishing Institute Proceedings 31(1), 51. https://doi.org/10.3390/proceedings2019031051

Borup, J., West, R. E. and Thomas, R. (2015). The impact of text versus video communication on instructor feedback in blended courses. Educational Technology Research and Development, 63(2), 161-184.

Botsify. (n.d.). Enhance Learning with Education Chatbot. Retrieved from https://botsify.com/education-chatbot

Boud, D. and Molloy, E. (2013). Rethinking models of feedback for learning: the challenge of design. Assessment and Evaluation in Higher Education, 38(6), 698-712. 
Brill, T. M., Munoz, L. and Miller, R. J. (2019). Siri, Alexa, and other digital assistants: A study of customer satisfaction with artificial intelligence applications. Journal of Marketing Management, 35(15-16), 1401-1436.

Brusilovsky, P. and Peylo, C. (2003). Adaptive and intelligent web-based educational systems. International Journal of Artificial Intelligence in Education (IJAIED), 13, 159-172.

Cotos, E. (2011). Potential of automated writing evaluation feedback. Calico Journal, 28(2), 420-459.

Creswell, J. W. (2012). Educational research: Planning, conducting, and evaluating quantitative and qualitative research (4th ed.). Boston, MA: Pearson.

Daneshvar, E. and Rahimi, A. (2014). Written corrective feedback and teaching grammar. Procedia-Social and Behavioral Sciences, 136, 217-221.

Dizon, G. (2017). Using intelligent personal assistants for second language learning: A case study of alexa. TESOL Journal, 8(4), 811-830.

Fadzil, M. and Munira, T. A. (2008). Applications of Artificial Intelligence in an Open and Distance Learning institution. In 2008 International Symposium on Information Technology, IEEE, 2008 , 1- 7, August, 2008.

Goldberg, Y. (2016). A primer on neural network models for natural language processing. Journal of Artificial Intelligence Research, 57, 345-420.

Goldsmith, L. (2014). Digital feedback: An integral part of the online classroom. Distance Learning, 11(2), 33.

Hamuddin, B. (2018, May). Blogs as powerful learning tools: the perception from efl students in riau main island Indonesia. In IOP Conference Series: Earth and Environmental Science, 156 (1), 1-6. IOP Publishing.

Heift, T. and Vyatkina, N. (2017). Technologies for teaching and learning L2 grammar. The handbook of technology and second language teaching and learning, 26-44.

Heift, T. and Nicholson, D. (2001). Web delivery of adaptive and interactive language tutoring. International Journal of Artificial Intelligence in Education, 12(4), 310-325.

Heift, T. (1998) Designed intelligence: A language teacher model. PhD Dissertation. Simon Fraser University, Canada.

Işik, A. H., and Aslan, G. (2018). Review and Proposal for Intelligent Distance Education. In I. Management Association (Ed.), Intelligent Systems: Concepts, Methodologies, Tools, and Applications (pp. 73-88). IGI Global. http://doi:10.4018/978-1-5225-5643-5.ch004 
Jyothirmayi, N., Soniya, A., Grace, Y., Reddy, C. K. K. and Murthy, B. R. (2019). Survey on Chatbot conversational system. Journal of Applied Science and Computations, 6(1), January 2019.

Kannan, J. and Munday, P. (2018). New trends in second language learning and teaching through the lens of ICT, networked learning, and artificial intelligence. In Fernández Juncal, C. and Hernández Muñoz, N. (Eds.), Vías de transformación en la enseñanza de lenguas con mediación tecnológica. Círculo de Lingüística Aplicada a la Comunicación, 76, 13-30. Retrieved from: http://dx.doi.org/10.5209/CLAC.62495

Kessler, G., and Plakans, L. (2008). Does teachers' confidence with CALL equal innovative and integrated use? Computer Assisted Language Learning, 21(3), 269-282.

Dolenc, K., and Aberšek, B. (2015). TECH8 intelligent and adaptive e-learning system: Integration into technology and science classrooms in lower secondary schools. Computers and Education, 82, 354-365.

Kumar, V. (2016). Introduction: is customer satisfaction (ir) relevant as a metric? Journal of Marketing, 80(5), 108-109.

Link, S., Dursun, A., Karakaya, K., and Hegelheimer, V. (2014). Towards better ESL practices for implementing automated writing evaluation. Calico Journal, 31(3),323-344, http://dx.doi. org/10.11139/cj.31.3.323-344

Looi, C.K., McCalla, G., Bredeweg, B. and Breuker, J. (2005), Artificial intelligence in education: Supporting learning through intelligent and socially informed technology, IOS Press, Amsterdam, NLD.

Lopatovska, I., Rink, K., Knight, I., Raines, K., Cosenza, K., Williams, H., ... and Martinez, A. (2019). Talk to me: Exploring user interactions with the Amazon Alexa. Journal of Librarianship and Information Science, 51(4), 984-997.

Lu, X. (2018). Natural language processing and intelligent computer-assisted language learning (ICALL). In Liontas, J.I. (Ed.), The TESOL Encyclopedia of English Language Teaching. Chichester: Wiley Blackwell. Electronic publication. http://doi: 10.1002/9781118784235.eelt0422

MATHiaU. (n.d.). Take your math classroom to the next level. Retrieved from https://www.carnegielearning.com/products/software-platform/mathiau-learning-software/ 
McCalla, G. (2000). The fragmentation of culture, learning, teaching and technology: implications for the artificial intelligence in education research agenda in 2010. International Journal of Artificial Intelligence in Education, 11(2), 177-196.

Mills, G. E., and Gay, L. R. (2019). Educational research: Competencies for analysis and applications. Pearson. One Lake Street, Upper Saddle River, New Jersey 07458.

Moore, M. G., and Kearsley, G. (2012). Distance education: A systems view of online learning. Cengage Learning.

Moussalli, S., and Cardoso, W. (2020). Intelligent personal assistants: can they understand and be understood by accented L2 learners?. Computer Assisted Language Learning, 33(8), 865-890.

Nenkov, N., Dimitrov, G., Dyachenko, Y., and Koeva, K. (2016, September). Artificial Intelligence Technologies for Personnel Learning Management Systems. 2016 IEEE 8th International Conference on Intelligent Systems. Proceedings, Sofia, Bulgaria, 189-194.

Nordrum, A. (2017). CES 2017: the year of voice recognition. IEEE Spectrum. Retrieved from http://spectrum.ieee.org/techtalk/consumerelectronics/gadgets/ces-2017-the-year-of-voice-recognition

Ozobot. (n.d.). STEAM made simple. Retrieved from https://ozobot.com/stem-education

Paul, A., Haque-Latif, A., Amin-Adnan, F., and Rahman, R. M. (2019). Focused domain contextual AI chatbot framework for resource poor languages. Journal of Information and Telecommunication, 3(2), 248-269.

Pokulevska, A. I. (2018). Experience of using skype as a means of foreign languages teaching efficiency improving. Information Technologies and Learning Tools, 68(6), 155-165.

Puspitasari, K. A. (2010). Student assessment. Policy and Practice. In T. Belawati and J. Baggaley (Eds.). Asian Distance Education (pp.60-65). New Delhi: SAGE.

Roll, I., and Wylie, R. (2016). Evolution and revolution in artificial intelligence in education. International Journal of Artificial Intelligence in Education, 26(2), 582-599.

Schulze, M. and T. Heift (2013). Intelligent CALL. In M. Thomas, H. Reinders and M. Warschauer (eds.), Contemporary computer-assisted language learning. London: Bloomsbury, p.249-265. 
Simonson, M., Smaldino, S., Albright, M. and Zvacek, S. (2006). Teaching and learning at a distance: Foundations of distance education (3rd ed.). Upper Saddle River, NJ: Pearson.

Sivakumar, S., Venkataraman, S. and Gombiro, C. (2015). A user-intelligent adaptive learning model for learning management system using data mining and artificial intelligence. International Journal for Innovative Research in Science and Technology, 1(10), 78-81.

Snatchbot. (n.d.). Enhancing the Classroom with Chatbots. Retrieved from https://snatchbot.me/education

Tafazoli, D., María, E. G. and Abril, C. A. H. (2019). Intelligent Language Tutoring System: Integrating Intelligent Computer-Assisted Language Learning into Language Education. International Journal of Information and Communication Technology Education (IJICTE), 15(3), 60-74.

Taskiran, A., and Yazici, M. (2021). Formative Feedback in Online Distance Language Learning: Boosting Motivation With Automated Feedback. In Motivation, Volition, and Engagement in Online Distance Learning (pp. 100-125). IGI Global. http://dx.doi.org/10.4018/978-1-7998-7681$\underline{6 . c h 005}$

Timms, M. J. (2016). Letting artificial intelligence in education out of the box: educational cobots and smart classrooms. International Journal of Artificial Intelligence in Education, 26(2), 701-712.

Underwood, J. (2017). Exploring AI language assistants with primary EFL students. In K. Borthwick, L. Bradley and S. Thouesny (Eds.), CALL in a climate of change: Adapting to turbulent global conditions - Short papers from EUROCALL, 317-321.

Wang, F. and Wang, S. (2012). A comparative study on the influence of automated evaluation system and teacher grading on students' English writing. Procedia Engineering, 29(2012), 993-997. http://doi:10.1016/j.proeng.2012.01.077

Wang, L., Qian, Y., Scott, M., Chen, G. and Soong, F. (2012). Computer-assisted audiovisual language learning. Computer, 45(6), 38-47.

Webber, B. L., and Nilsson, N. J. (Eds.). (2014). Readings in artificial intelligence. Morgan Kaufmann.

Wiranti, N. A. (2013). Improving students' speaking competence by using jazz chants (A Classroom Action Research at the Third Semester of English De- 
partment, Teacher Training and Education Faculty of Purwokerto Muhammadiyah University in the Academic Year of 2012-2013) (Doctoral dissertation, UNS (Sebelas Maret University)).

\section{Kaynakça Bilgisi / Citation Information}

Göksel, N. (2021). Anadolu University open education faculty students' opinions on the use of artificial intelligence based systems and applications. OPUS-International Journal of Society Studies, 18(43), 6119-6142. DOI: 10.26466/opus. 937331. 